\title{
Ultrastructural analysis of plasma cells in coeliac patients
}

\author{
M. GUIX, J. M. SKINNER, AND R. WHITEHEAD \\ From the Department of Pathology, Flinders Medical Centre, Bedford Park, South Australia
}

SUMMARY By accurate morphometry the length of the rough endoplasmic reticulum (RER) was estimated in electron micrographs of a population of jejunal plasma cells in biopsies obtained from normal volunteers, untreated coeliac disease patients, and coeliac disease patients treated for one year on a gluten free diet. Increase in length or hypertrophy of the endoplasmic reticulum is an indication of increased protein synthesis of the cell (Ghadially, 1977). An increase compared with normal length was demonstrated in the mean length of the plasma cell rough endoplasmic reticulum in plasma cells obtained from both groups of coeliac patients. This estimate of increased protein production-in this case immunoglobulin-indicates an increase in the immunological activity of plasma cells even after treatment and suggests not only a reaction to dietary gluten but probably to other antigens also.

There has been ample evidence over the past 20 years that an immunological mechanism is involved in some way in coeliac disease (Rubin et al., 1965; LePore, 1958; Kivel et al., 1964; Harris et al., 1967; Asquith et al., 1969; Blecher et al., 1969; Brown et al., 1969; Hobbs et al., 1969; Douglas et al., 1970; Wall et al., 1970; Rubin, 1971; Strober et al., 1974; Holmes et al., 1976; Lancaster-Smith et al., 1976). It is known that there is an increase in the number of plasma cells in the jejunal mucosa of coeliac patients and, after treatment on a gluten free diet, the proportion of these cells returns to normal or almost normal (Asquith, 1974; Holmes et al., 1974; Lancaster-Smith et al., 1976). There have also been qualitative and quantitative studies related to the proportions of different types of immunoglobulinproducing-plasma cells in the lamina propria (Douglas et al., 1970; Søltoft, 1970; Pettingale, 1971; Lancaster-Smith et al., 1974; Savilahti, 1974), but hitherto there have been no attempts to quantify the ultrastructural features of plasma cells in an objective manner so that an estimation of their functional state can be made in coeliac patients both before and after treatment.

\section{Method}

The plasma cells studied were in jejunal biopsies obtained in the usual way under radiological control

Received for publication 11 January 1979 from normal volunteers and patients with coeliac disease whose diagnosis was based on clinical and morphological grounds-that is, the presence of malabsorption, total villous atrophy, and crypt hyperplasia of the jejunal mucosa when the patient was first seen, clinical and morphological improvement after one year on a gluten free diet, and the reappearance of morphological abnormalities after further gluten challenge. The biopsies of the patients on a gluten free diet were subjectively indistinguishable from normal using the usually accepted criteria (Whitehead, 1973).

A portion of each of the biopsy specimens, taken at random from the whole specimen after removal of about half the specimen for enzyme analysis, was fixed in $5 \%$ glutaraldehyde, processed and embedded in Araldite (Ciba-Geigy) resin. Sections were cut at approximately 0.5 microns using an LKB ultra microtome and floated onto water. The thinner sections were identified by their silver-grey colour and were produced entirely by chance. Some were picked up randomly as they floated on the water bath and placed on copper grids. They were examined using a Philips 201C electron microscope at a magnification of $\times 1939$ (determined by reference to particles of known size). Only those fields between grid bars could be examined and this was determined during preparation without observer choice. They were then photographed. In order to assess the activity of plasma cells the length of the endoplasmic reticulum (RER) was measured on the microphoto- 
graphs. A grid was prepared which had five rows of 10 parallel lines of equal length placed in such a way that the end points of the lines of each row formed an equilateral triangle with the end points of the line immediately above. This grid was placed at random by dropping it over the microphotographs (Fig. 1) and the number of intercepts of the lines with the RER were counted. Thus the cells and the position of the counting grid over the plasma cells were selected randomly. The final length of the RER was obtained by multiplying the number of intercepts (I) by a tenth of the overall width of the grid in millimetres (W) and by a further $10^{3}$ to convert this into microns, this then being divided by the final magnification (M) of the photographic enlargementthat is, $\frac{\mathrm{I} \times \mathrm{W} \times 10^{3}}{\mathrm{M}}$. Only one plane of each plasma cell was measured, providing that it contained a recognisable nucleus. It was assumed that the RER, though a series of long curved lines, was in fact made up of a series of short straight lines randomly distributed (Weibel, 1969). The number of cells which needed to be measured to obtain accurate results was found by the 'quotient of accumulative addition of values' (Dunnill, 1968) in which the length of the RER was related to the maximum diameter of the cell. In Fig. 2 it can be seen that no less than 17 cells had to be measured in each case to get accurate results. The maximum diameter reference point was chosen purely for convenience of measurement but the cell area determined by point counting would be as reliable and probably show that fewer cells need be counted as it is a more stable denominator. In effect, therefore, the accuracy of this estimate of RER was probably increased as more intercepts were counted. A total of 246 cells was measured from different groups of jejunal biopsies: 100 plasma cells from five normal biopsy specimens, 75 from biopsy specimens of four

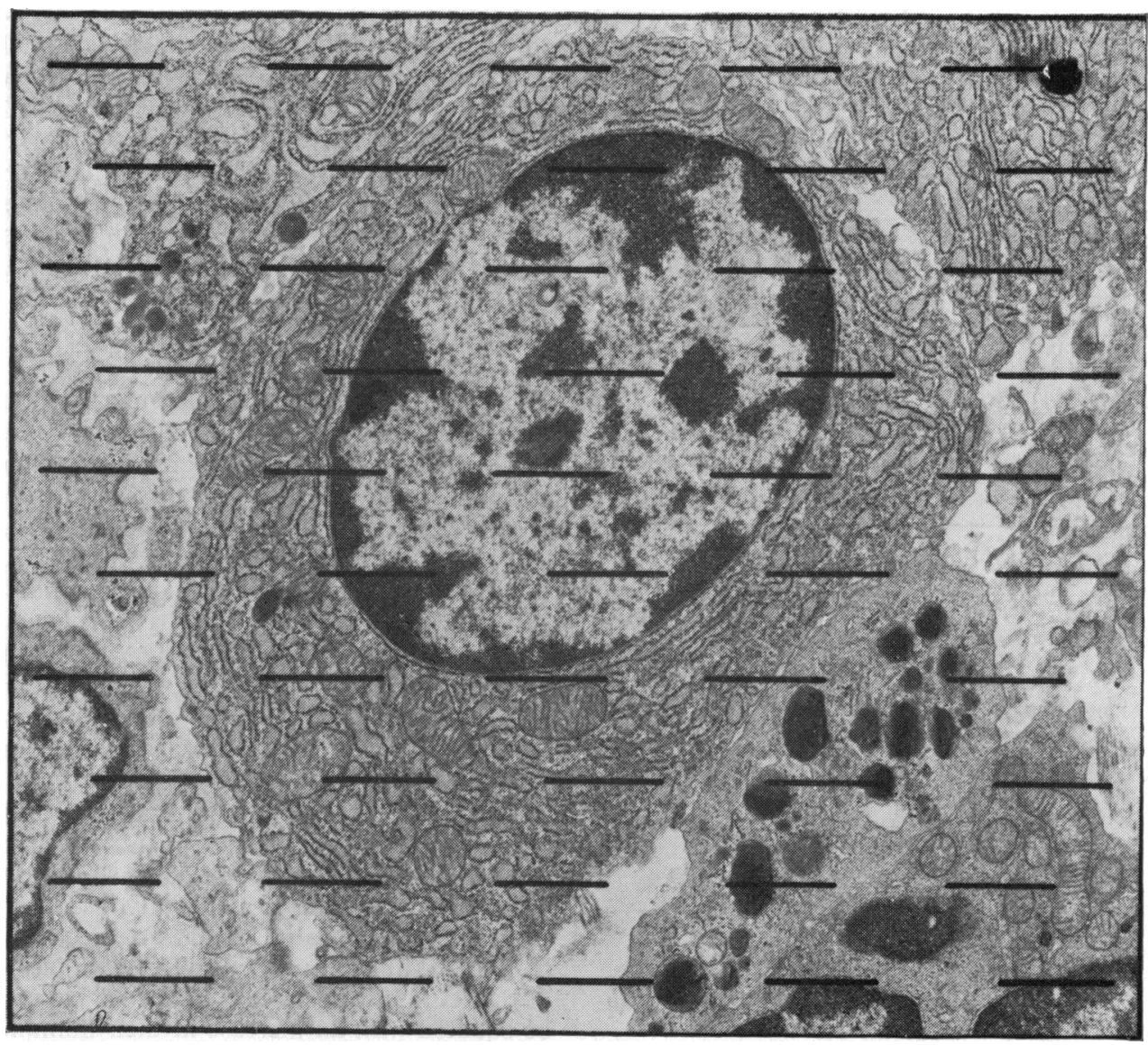

Fig. 1 Grid placed over an electronmicrophotograph of a plasma cell to count the number of intercepts with the RER. $\times 2000$ (original magnification). 


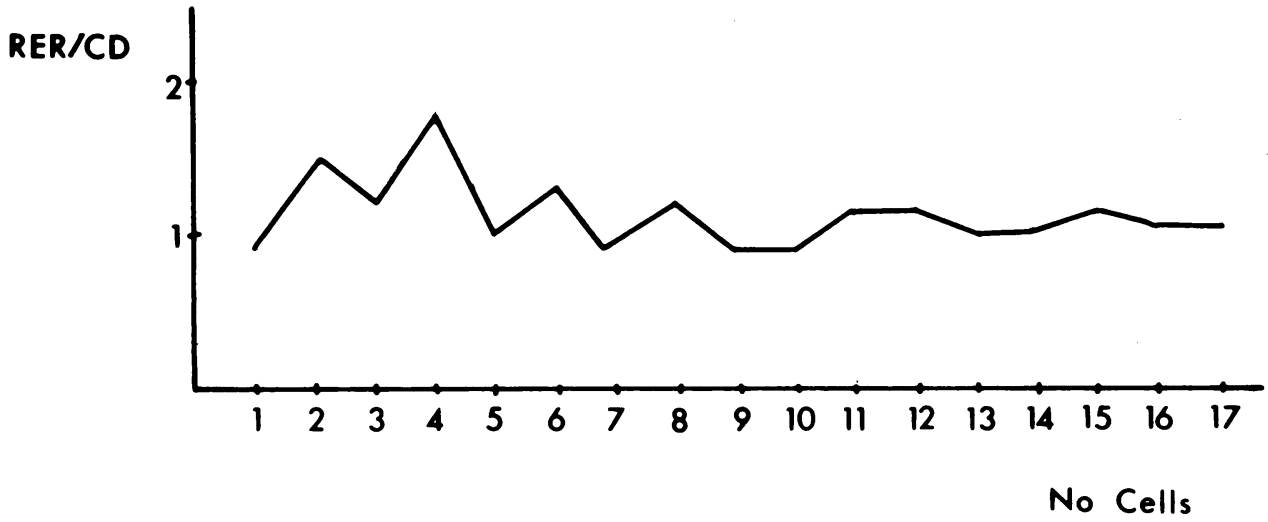

Fig. 2 Graph of the quotient of accumulative addition of values between the number of intercepts with the RER and the diameter of the cell $(L . R E R / C D)$. The quotient remains stable after 17 plasma cells examined.

untreated coeliac patients, and 71 from biopsy specimens of four patients treated for one year on a gluten free diet. Statistical analysis was performed using the $t$ test and carried out on a DEC 10 computer using programmes from the Statistical Package for the Social Sciences (Nie et al., 1975).

\section{Results}

Results from different groups of biopsies were expressed as mean values and standard deviations (Table). Plasma cells from the group of normal subjects had a mean length of the RER of 41.64 microns, with a standard deviation (s) of 6.14. Those from untreated patients showed a mean of $61 \cdot 74$

Table Mean values $(X)$ and standard deviations $(s)$ of the length of RER in normal subjects and coeliac patients

\begin{tabular}{|c|c|c|c|}
\hline & $X$ & $s$ & $\begin{array}{l}\text { Mean and } S D \text { from } \\
\text { different group means }\end{array}$ \\
\hline \multicolumn{4}{|c|}{ Normal subjects } \\
\hline Case 1 & $38 \cdot 85$ & $21 \cdot 18$ & \\
\hline Case 2 & $32 \cdot 47$ & $16 \cdot 70$ & \\
\hline Case 3 & $47 \cdot 74$ & $22 \cdot 30$ & $X=41 \cdot 64$ \\
\hline Case 4 & $46 \cdot 11$ & 16.44 & $s=6.14$ \\
\hline Case 5 & 43.03 & $16 \cdot 48$ & \\
\hline \multicolumn{4}{|c|}{ Untreated coeliac patients } \\
\hline Case 6 & $55 \cdot 01$ & $17 \cdot 02$ & \\
\hline Case 7 & $54 \cdot 35$ & $18 \cdot 38$ & $X=61 \cdot 74$ \\
\hline Case 8 & $59 \cdot 89$ & $19 \cdot 70$ & $s=10.93$ \\
\hline Case 9 & $77 \cdot 71$ & $18 \cdot 25$ & \\
\hline \multicolumn{4}{|c|}{ Treated coeliac patients } \\
\hline Case 10 & $59 \cdot 34$ & $24 \cdot 46$ & \\
\hline Case 11 & $51 \cdot 79$ & 17.96 & $X=59 \cdot 01$ \\
\hline Case 12 & $66 \cdot 74$ & $31 \cdot 68$ & $s=6.13$ \\
\hline Case 13 & $58 \cdot 17$ & 13.92 & \\
\hline \multicolumn{4}{|c|}{ 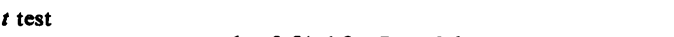 } \\
\hline \multicolumn{4}{|c|}{$\begin{array}{l}\text { untreated: } t 3.51 \text { d.f. } \quad 7 \mathrm{P}<0.01 \\
\text { treated: } t 4.21 \text { d.f. } 7 \mathrm{P}<0.01\end{array}$} \\
\hline
\end{tabular}

$(\mathrm{s}=10.93)$ and from treated patients a mean of $59 \cdot 01(\mathrm{~s}=6 \cdot 13)$.

Analysis between pairs of the groups showed that the length of RER in both the plasma cells from untreated coeliacs and from treated coeliacs was different from normal subjects at the $5 \%$ level conventionally chosen, the value of $t$ for the first comparison in a two-tailed test being $3.51(\mathrm{P}<0.01)$ and for the second $4.21(\mathrm{P}<0.01$ at 7 degrees of freedom). There was no significant difference between plasma cells from treated and untreated groups.

\section{Discussion}

In the lamina propria of jejunal mucosa of untreated coeliac patients there is a significant increase in the number of plasma cells and a decrease in the number of lymphocytes, but these return to normal or near normal after a gluten free diet (Asquith, 1974; Holmes et al., 1974; Lancaster-Smith et al., 1976).

Quantitative studies of the absolute numbers of immunoglobulin-containing cells in coeliac disease show a significant increase in $\operatorname{IgA}, \operatorname{IgM}$, and $\operatorname{IgG}$ producing cells compared with normal. The increase is greatest in IgA and IgM cells (Douglas et al., 1970; Søltoft, 1970; Pettingale, 1971; LancasterSmith et al., 1974; Savilahti, 1974).

These studies provide only part of the available information concerning the quantitative aspect of plasma cells in coeliac disease and objective data as to their immunological activity based on ultrastructural grounds are lacking. For instance, Shiner (1973) in a subjective study, suggested that dilatation of the RER in plasma cells in coeliac patients could be equated with an increase in their immunological activity, but this is contrary to the generally accepted view that dilatation of the RER in whatever cell 
type signifies some defect in the egress of secretory material (Ghadially, 1977). Few cells with dilated RER were seen in this study and were no more common in the coeliac group. It is known that the RER is the site of production of immunoglobulin in plasma cells and the length of the RER is an indication of activity of the cell (Ghadially, 1977). In this study the length of the RER was measured and used as an index of immunological activity. Though there is an overlap between the groups, based on the length of RER, there is an increase in the number of 'activated' cells when plasma cells from coeliac patients are compared with those of normal subjects.

This probably reflects the different distribution of the various stages in the continuum of plasma cell differentiation in this disease. It also demonstrates the involvement of a humoral immunological reaction as the protein produced (immunoglobulin) is presumably secreted. Cells from treated patients after one year on a gluten free diet also show evidence of activation, although the overall architecture of the jejunal mucosa is normal. This finding suggests that a humoral immunological reaction persists even in the absence of dietary gluten and is possibly an ongoing response to other antigens. A similar conclusion has been drawn by Baklien et al. (1977) based on a study of plasma cells both by their numbers in lamina propria determined by Ig class and their position in the mucosa. Prolonged antigenic stimulation and plasma cell activation are known to predispose to lymphoma in other organs where immunological mechanisms are involved in the disease process (Cox, 1964; Talal et al., 1967). It is pertinent, therefore, that in the view of some (Holmes et al., 1976; Thompson, 1976) a gluten free diet does not remove the liability to lymphoma in coeliac subjects.

According to these results we conclude that a humoral immunological reaction occurs in coeliac disease, and that a similar reaction is probably developed to antigens other than gluten, but this possibly non-specific reaction does not affect to any great extent the general morphology of the jejunal mucosa.

This study was supported in part by a grant from Fundación Juan March (Spain), and by the Flinders Medical Centre (South Australia).

\section{References}

Asquith, P. (1974). Cell mediated immunity in coeliac disease. In Coeliac Disease: Proceedings of the Second International Coeliac Symposium, pp. 242-262. Edited by W. T. J. M. Hekkens and A. S. Peña. Stenfert Kroese: Leiden.
Asquith, P., Thompson, R. A., and Cooke, W. T. (1969). Serum-immunoglobulins in adult coeliac disease. Lancet, 2, 129-131.

Baklien, K., Brandtzaeg, P., and Fausa, O. (1977). Immunoglobulins in jejunal mucosa and serum from patients with adult coeliac disease. Scandinavian Journal of Gastroenterology, 12, 149-159.

Blecher, T. E., Brzechwa-Ajdukiewicz, A., McCarthy, C. F., and Read, A. E. (1969). Serum immunoglobulins and lymphocyte transformation studies in coeliac disease. Gut, 10, 57-62.

Brown, D. L., Cooper, A. G., and Hepner, G. W. (1969). IgM metabolism in coeliac disease. Lancet, 1, 858-861.

Cox, M. T. (1964). Malignant lymphoma of the thyroid. Journal of Clinical Pathology, 17, 591-601.

Douglas, A. P., Crabbé, P. A., and Hobbs, J. R. (1970). Immunochemical studies of the serum, intestinal secretions and intestinal mucosa in patients with adult celiac disease and other forms of the celiac syndrome. Gastroenterology, $59,414-425$.

Dunnill, M. S. (1968). Quantitative Methods in Histology. In Recent Advances in Clinical Pathology, pp. 401-416. Series 5. Edited S. C. Dyke. Churchill: London.

Ghadially, F. N. (1977). Ultrastructural Pathology of the Cell, pp. 222-254. Butterworths: London.

Harris, O. D., Cooke, W. T., Thompson, H., and Waterhouse, J. A. H. (1967). Malignancy in adult coeliac disease and idiopathic steatorrhoea. American Journal of Medicine, 42, 899-912.

Hobbs, J. R., Hepner, G. W., Douglas, A. P., Crabbé, P. A., and Johansson, S. G. O. (1969). Immunological mystery of coeliac disease (Letter). Lancet, 2, 649-650.

Holmes, G. K. T., Asquith, P., and Cooke, W. T. (1976). Cell-mediated immunity to gluten fraction III in adult coeliac disease. Clinical and Experimental Immunology, 24, 259-265.

Holmes, G. K. T., Asquith, P., Stokes, P. L., and Cooke, W. T. (1974). Cellular infiltrate of jejunal biopsies in adult coeliac disease in relation to gluten withdrawal. Gut, 15, 278-283.

Holmes, G. K. T., Stokes, P. L., Sorahan, T. M., Prior, P., Waterhouse, J. A. H., and Cooke W. T. (1976). Coeliac disease, gluten free diet, and malignancy. Gut, 17, 612-619.

Kivel, R. M., Kearns, D. H., and Liebowitz, D. (1964). Significance of antibodies to dietary proteins in the serums of patients with nontropical sprue. New England Journal of Medicine, 271, 769-772.

Lancaster-Smith, M., Kumar, J., and Clark, M. L. (1974). Immunologic phenomena following gluten challenge in the jejunum in patients with adult coeliac disease and dermatitis herpetiformis. In Coeliac Disease: Proceedings of the Second International Coeliac Symposium, pp. 173-175. Edited by W. T. J. M. Hekkens and A. S. Peña. Stenfert Kroese: Leiden.

Lancaster-Smith, M., Packer, S., Kumar, P. J., and Harries, J. T. (1976). Cellular infiltrate of the jejunum after reintroduction of dietary gluten in children with treated coeliac disease. Journal of Clinical Pathology, 29, 587-591.

LePore, M. J. (1958). Long-term or maintenance adrenal steroid therapy in non-tropical sprue. American Journal of Medicine, 25, 384-390.

Nie, N. H., Hadlai Hull, C., Jenkins, J. G., Steinbrenner, K., and Bent, D. H. (1975). Statistical Package for Social Sciences. McGraw-Hill: New York.

Pettingale, K. W. (1971). Immunoglobulin-containing cells in the coeliac syndrome. Gut, 12, 291-296.

Rubin, W., Fauci, A. S., Sleisenger, M. H., and Jeffries, G. H. (1965). Immunofluorescent studies in adult coeliac disease. Journal of Clinical Investigation, 44, 475-485.

Rubin, W. (1971). Celiac disease. American Journal of Clinical 
Nutrition, 24, 91-111.

Savilahti, E. (1974). Immunofluorescence in coeliac disease. In Coeliac Disease: Proceedings of the Second International Coeliac Symposium, pp. 163-172. Edited by W. T. J. M. Hekkens and A. S. Peña. Stenfert Kroese: Leiden.

Shiner, M. (1973). Ultrastructural changes suggestive of immune reactions in the jejunal mucosa of coeliac children following gluten challenge. Gut, 14, 1-12.

Søltoft, J. (1970). Immunoglobulin-containing cells in non-tropical sprue. Clinical and Experimental Immunology, 6, 413-420.

Strober, W., Falchuck, Z. M., Nelson, D. L., and Gebhard, R. M. (1974). The pathogenisis of gluten-sensitive enteropathy. In Progress in Immunology, 2, vol. 4, pp. 221-229. Edited by L. Brent and J. Holborow. North Holland:
Amsterdam.

Talal, N., Sokoloff, L., and Barth, W. F. (1967). Extrasalivary lymphoid abnormalities in Sjögren's syndrome (reticulum cell sarcoma, "pseudolymphoma", macroglobulinemia). American Journal of Medicine, 43, 50-65.

Thompson, H. (1976). Pathology of coeliac disease. Current Topics in Pathology, 63, 49-75.

Wall, A. J., Douglas, A. P., Booth, C. C., and Pearse, A. G. E. (1970). Response of the jejunal mucosa in adult coeliac disease to oral prednisolone. Gut, 11, 7-14.

Weibel, E. R. (1969). Stereological principles for morphometry in electron microscopic cytology. International Review of Cytology, 26, 235-302.

Whitehead, R. (1973). Mucosal Biopsy of the Gastrointestinal Tract, pp. 83-95. Saunders: London. 